permitted; but to an intelligent and earnest judge it soon became apparent that the services of a man skilled in the examination of juvenile offenders was of great assistance to him in the adjudication of the cases. Finally, this assistance has become so valuable as to be indispensable. Judge Pinckney, the exceptionally able incumbent of the bench at the Juvenile Court, has averred that he could not go on with his present work without the help of Dr. Healy, who has been the institute's director since the beginning, or some equally efficient aid. So evident has the value of this work become to judiciary, police, attorneys, probation officers, criminologists and sociologists, that emissaries from many cities in this country and Europe have come to observe and have gone home to institute similar bureaus. Seattle was the first to follow us, Boston next, Munich soon after, and now the Municipal Court of Chicago has its own expert.

For five years Mrs. W. F. Dummer and her sisters supported the institute as a private benefaction with public functions, but now Cook County has awakened to its duty and opportunity, and has taken over the institute as an official adjunct of the Juvenile Court. Medical men everywhere should know of and appreciate the importance of this innovation, because,

Fourth, when the opportunity arises for them to assist in the installation of similar officers in their own cities and towns, it is to be hoped that they will earnestly further this step forward in scientific research, common humanity and the administration of justice.

Hugh T. Patrick, M.D., Chicago.

[An advertisement for a director for the institute appears this week under Announcements, advertising page 20.-Ev.]

\section{Postgraduate Study: Facilities in New York}

To the Editor:-I did not realize how far Boston is from New York until I read in The Journal, Dec. 12, 1914, p. 2150. the communication on postgraduate study by Dr. Hugh Payne Greeley of that intellectual center, which is concluded thus: "Let us at once set to work and organize ourselves for this task and give to American physicians practical postgraduate work in our own language, and with our own trade-mark."

For nearly thirty-three years, there have been actively and successfully engaged in "practical postgraduate work" and in "our own language" and with a distinctly American "trademark," two organizations of well-known medical teachers who have had in attendance on their demonstrations and at their lectures some 50,000 practicing physicians from our own continent and from all over the world.

The New York Polyclinic Medical School and Hospital and the New York Post-Graduate Medical School and Hospital have expended in buildings and equipment approximately $\$ 3,000,000$, and nowhere in the world can be found better opportunities for a practical postgraduate training and "brushing up" than are afforded by these schools. Over 300 physicians and surgeons are devoting their time to this work, without one dollar of remuneration, and many of these have, in addition, given largely of their means to make postgraduate teaching in America the great success it has proved to be.

May I cite our Bay State brother to an extract from the Boston Transcript of Nov. 17, 1914, a paper which may be profitably read by every good American?

"Nor can there be any question that the establishment of the Polyclinic (1881) was the chief stimulus to the advance of medical thought and science in the United States; a stimulus that was felt, not only throughout this country, in all of whose important cities one or more postgraduate medical schools have been founded, but across the sea as well, where the system has been adopted in London and other cities!"

No matter how "tremendous" may be "the impetus to postgraduate instruction on account of the European War," the two great schools of the metropolis are ready for the hoped-for influx and will meet every requirement.

John A. Wyeth, M.D., New York.

\section{Provision for Infants in Chicago Municipal Tuberculosis Sanitarium}

To the Editor:-In connection with the article of Dr. Alfred F. Hess of New York on "The Neglect to Provide for the Infant in the Antituberculosis Program" (The Journal, Dec. 19, 1914, p. 2176), I wish to state that the Chicago Municipal Tuberculosis Sanitarium, which is to open its doors about March 1, contains a provision for the new-born infants of tuberculous mothers. A description of this provision was given by Dr. Charles S. Bacon of this city, in his article published in The Journal, Sept. 6, 1913, p. 750 .

The Chicago Municipal Tuberculosis Sanitarium which, with its ultimate capacity of 950 beds, is the largest municipal sanitarium in the country, has a comprehensive provision for children ( 240 beds for ambulant cases and a special provision for bed cases in the infirmary).

In addition to this the sanitarium has a nursery to which two classes of new-born infants will be admitted: (1) the new-born infants of tuberculous mothers confined in the maternity department of the sanitarium, and (2) the newborn infants of tuberculous mothers remaining at home, who are unable to arrange for safe and proper care of the infant at home.

This is the first arrangement of its kind in the country, and it will no doubt prove of great value in meeting one of the great needs of the tuberculosis situation in a large community. The initial provision in the Chicago Municipal Tuberculosis Sanitarium is for twenty infants, but this will be gradually extended to meet the needs of the situation.

I was very glad to learn from the article of Dr. Hess that this important phase of the tuberculosis situation is in a way to receive due recognition in New York.

Theodore B. SACHS, M.D., President. Chicago Municipal Tuberculosis Sanitarium.

\section{Queries and Minor Notes}

Anonymous Communications and queries on postal cards will not be noticed. Every letter must contain the writer's name and address, but these will be omitted, on request.

\section{DENATURED ALCOHOL}

To the Editor:-1. By what process is alcolol denatured?

2. Can it safely be used for bathing purposes? J. G. Petrit, M.D., Weston, W. Va.

Answer.-1. Alcohol ordinarily is denatured according to the following formula: "To 100 parts by volume of 90 per cent. alcohol add 10 parts of approved wood alcohol and one-half of 1 part of approved benzin." In other cases the use of 2 parts of approved alcohol and one-half part of approved pyridin is permitted. Information on this question can be obtained by addressing the Treasury Department, Bureau of Internal Revenue, Washington, D. C.

2. The external use of any alcohol containing wood spirits is unsafe.

\section{REMOVAL OF RUST FROM INSTRUMENTS}

To the Editor:-Can you give me a formula for removing rust from instruments?

Answer.-Instruments can be prevented from rusting in the process of sterilization by adding some sodium bicarbonate to the water in which they are boiled. A good polishing powder may be of aid in removing rust already formed.

\section{LITERATURE ON FUNCTIONAL TESTS OF THE LIVER AND} PANCREAS

To the Editor:-I should like to be informed as to the nature and methods of some of the newer tests of the functioning power of the liver and pancreas. These new tests do not seem to be mentioned in any of the newer works on diagnostic tests which I know of. Any information concerning them, or any literature which describes them, will be exceedingly opportune. 